Article

\title{
Impact of Sea Breeze Circulation on the Transport of Ship Emissions in Tangshan Port, China
}

\author{
Fang Shang ${ }^{1}$, Dongsheng Chen ${ }^{1, *} \mathbb{C}$, Xiurui Guo ${ }^{1}$, Jianlei Lang ${ }^{1} \mathbb{D}$, Ying $\mathrm{Zhou}^{1}$, Yue $\mathrm{Li}^{2}$ and \\ Xinyi Fu ${ }^{1}$ \\ 1 Key Laboratory of Beijing on Regional Air Pollution Control, Beijing University of Technology, \\ Beijing 100124, China; S201705068@emails.bjut.edu.cn (F.S.); guoxiurui@bjut.edu.cn (X.G.); \\ jllang@bjut.edu.cn (J.L.); y.zhou@bjut.edu.cn (Y.Z.); fuxinyi@emails.bjut.edu.cn (X.F.) \\ 2 Transport Planning and Research Institute, Ministry of Transport, Beijing 100028, China; \\ lijiayue1107@163.com \\ * Correspondence: dschen@bjut.edu.cn; Tel.: +86-10-6739-1659
}

Received: 22 October 2019; Accepted: 9 November 2019; Published: 18 November 2019

\begin{abstract}
A sea breeze is a local circulation that occurs in coastal regions from the poles to the equator. The adverse influence of ship emissions on air quality in coastal areas may be aggravated by the onshore flow of sea breeze circulation. However, our knowledge regarding the evolution of ship-emitted pollutants during a specific sea breeze episode is still limited. To address this knowledge gap, this study investigated the evolution of ship emissions during a sea breeze episode that occurred on 29 June, 2014 in Tangshan port in China by employing the WRF/Chem model. $\mathrm{NO}_{2}$, one of the primary pollutants emitted by ships, was selected as the target pollutant for investigation. The results indicate that the ground level $\mathrm{NO}_{2}$ concentration was considerably affected by sea breeze circulation. Although the onset of the sea breeze was delayed until nearly midday due to offshore synoptic winds, ship-emitted $\mathrm{NO}_{2}$ was transported to more than $100 \mathrm{~km}$ inland with the penetration of the sea breeze. Further investigation found that the averaged concentration of ship-contributed $\mathrm{NO}_{2}$ during the episode showed an evident downward trend as the distance from the coastline increased. Vertically, the shallow atmospheric boundary layer (ABL) on the sea limited the vertical dispersion of ship emissions, and the pollutant was transported shoreward by the sea breeze within this shallow ABL. The height of the ABLs is lowered in coastal regions due to the cooling effect of sea breezes which brings the cool marine air to the hot land surface. Ship-contributed $\mathrm{NO}_{2}$ was mostly trapped in the shallow ABL; thereby, its concentration increased.
\end{abstract}

Keywords: air quality; ship emissions; sea breeze; Tangshan port; WRF/Chem

\section{Introduction}

The adverse influence of ship emissions on air quality in coastal and port regions has been extensively reported worldwide [1-18]; this problem can be aggravated when there is an onshore wind [19-22]. Usually, a sea breeze is the main reason for this onshore flow, except in the case of a shoreward-blowing synoptic wind.

A sea breeze is a local circulation that occurs in coastal locations due to a thermal contrast between land and sea [23]. Previous studies have reported that sea breeze circulations can penetrate more than 100 kilometers inland horizontally, and reach more than 3000 meters vertically [24-27]. Furthermore, sea breezes continuously occur at specific geographic locations [28]. Previous studies in China's Bohai Bay [29] and Jiangsu Province [24] revealed that the average occurrence frequency of a sea breeze ranged from $41.2 \%$ to $52.8 \%$. Therefore, the transport and dispersion of air pollutants in coastal areas may be significantly influenced by these circulations [28,30,31], and it is useful to investigate the impact of these frequently-occurring coastal circulations on air quality. 
Various mechanisms of sea breeze circulations affecting the air quality in coastal areas have been proposed and reviewed by many researchers [32-39], e.g., the recirculation of pollutants associated with sea breezes and the thermal internal boundary layer (TIBL) are often designated as the causes of persistent air pollution problems in coastal areas [32]. (1) Recirculation of pollutants. Owing to the presence of sea breeze circulations, polluted air that is initially transported away from the emitting source by the seaward return flow can be recirculated landward, resulting in an accumulation of pollutants in coastal areas [40,41]. As Levy et al. [42] reported, sea breezes can cause pollutants to recirculate over the same airshed as much as three times a day, and the air pollution over coastal areas may thus be aggregated. (2) Thermal internal boundary layers (TIBLs). TIBLs form near the Earth's surface when cool, stable marine air advects over a hot land surface and becomes thermodynamically unstable near the surface while remaining unmodified above. The unmodified marine air acts as a cap that prevents vertical mixing between destabilized marine air within the TIBL and the continental air above, which therefore limits the vertical extent of the dispersion of air pollutants [32,41,43-46]. Locally-emitted pollutants are then trapped in this shallow TIBL [28,47], resulting in an increase in their concentrations.

Ship emissions are a major source of pollutants in coastal regions. Previous studies on ship emission inventories indicate that high emission intensities are generally located in port areas and major shipping channels near the coast $[13,14,20,48,49]$, and $\sim 70 \%$ of ship emissions occur within $400 \mathrm{~km}$ of the coastline according to Corbett et al. [50] and Eyring et al. [51,52]. The transport and dispersion of ship emissions may thus often be dependent on sea breezes. Investigating the evolution of ship-emitted pollutants during sea breeze episodes is necessary to improve our understanding of how, and to what extent, ship emissions impact air quality in coastal regions.

However, present studies that have quantified the impacts of ship emissions have primarily focused on overall contributions based on long-term (e.g., annual or seasonal) modeling/observations [1-17,53-57]. The evolution of ship-emitted pollutants during a specific sea breeze episode has not been addressed in detail. The inability to gain insight into this subject limits our understanding of the impact of ships on air quality, especially in coastal regions. To fill this knowledge gap, a sea breeze episode that occurred in Tangshan port (the third largest port in China in terms of cargo throughput [58]) in the summer of 2014 was selected as the target period to investigate the influence of sea breezes on the evolution of ship emissions. The Weather Research and Forecast model, coupled with the Chemistry (WRF/Chem) modeling system [59], was employed based on a ship emission inventory with a high temporal-spatial resolution [60]. The results of this study may serve as a reference to further our understanding of how ship emissions impact the air quality during sea breeze episodes, thereby formulating standards and policies that are more effective for the abatement of ship emissions.

\section{Methodology}

\subsection{Study Area}

Tangshan Port, located on the coast of Tangshan city, which borders Beijing in the northwest and Tianjin in the southwest, is an important maritime transport hub in northern China. As one of the largest comprehensive ports in the world, its total cargo throughput was 637 million tons in 2018, ranked third in China and among the top 10 in the world [58]. Figure 1 presents a map of the study area and depicts the nested modeling domains (detailed in Section 2.2.2), meteorological stations, and major ports used in this study.

\subsection{Input Data and Model Configuration}

\subsubsection{Input Data}

In this study, the WRF/Chem modeling system was employed to investigate the evolution of ship-emitted pollutants during a sea breeze episode on July 29, 2014. The input data of the modeling system are described as follows: 
Emission data. The emission data used in this study include: (1) land-based emissions extracted from the the Multi-resolution Emission Inventory of China [61-65], (2) ship emissions extracted from the a high-spatiotemporal-resolution ship emission inventory in China developed by Chen et al. [60], (3) biomass burning emissions reported by Zhou et al. [66], and (4) biogenic emissions that were calculated online using the WRF Preprocessing System (WPS), based on the United States Geological Survey (USGS) land-use classification. In this study, the emission data with a temporal resolution of 1 hour was used to meet the requirements of the air quality model. The $\mathrm{NO}_{2}$ emissions from the main sectors are presented in Table 1.
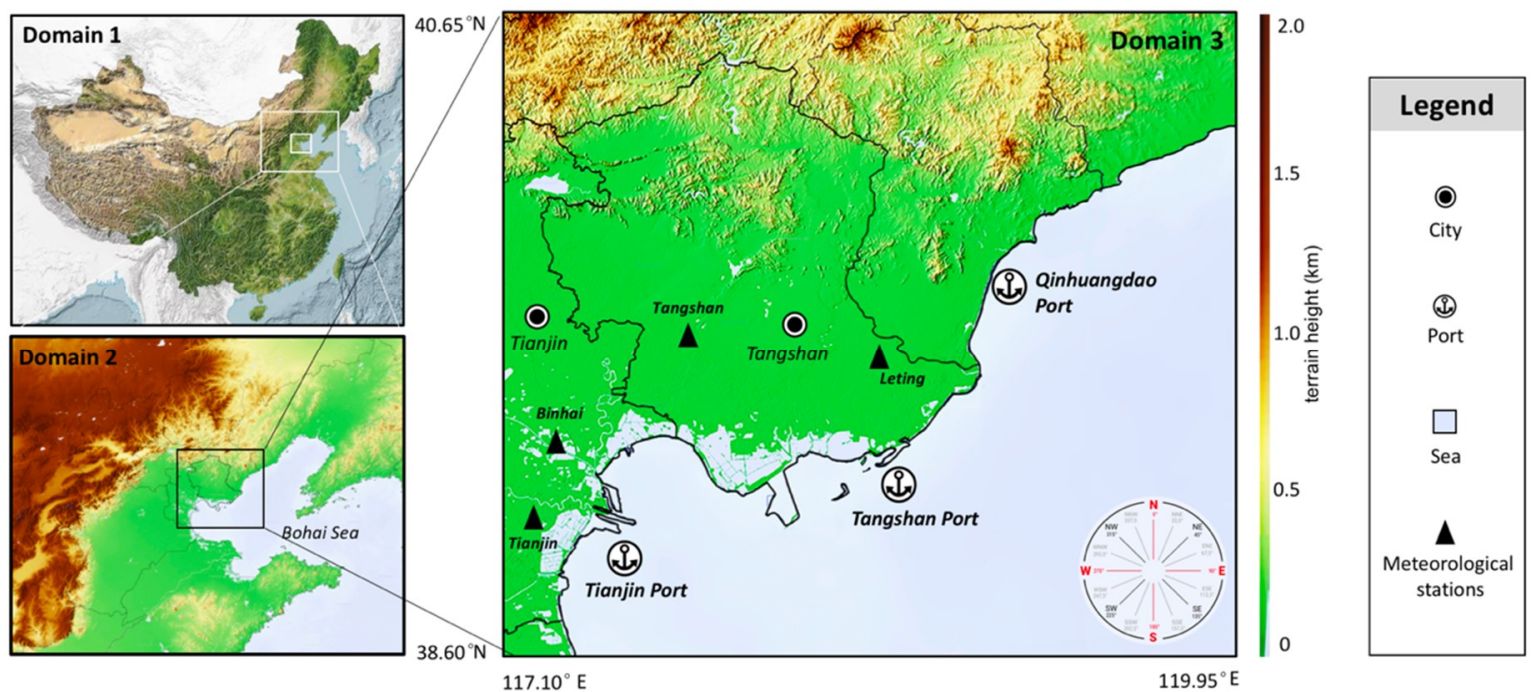

Figure 1. Sketch map of the study area.

Table 1. Input data of land-based and ship emissions.

\begin{tabular}{ccc}
\hline Sectors & Emission (tons/month) & Contribution of the emission \\
\hline Transportation & 12979 & $15.56 \%$ \\
Industry & 37330 & $44.75 \%$ \\
Residential & 715 & $0.86 \%$ \\
Power & 24836 & $29.77 \%$ \\
Biomass burning & 535 & $0.64 \%$ \\
Total non-ship emissions & 76395 & $91.58 \%$ \\
Ship emissions & 7018 & $8.42 \%$ \\
Total emissions & 83413 & $100 \%$ \\
\hline
\end{tabular}

Meteorological data. The meteorological input for the WRF/Chem model was generated from the National Centers for Environmental Prediction (NCEP) Final Analysis (FNL) data with a spatial resolution of $1^{\circ} \times 1^{\circ}$ and a temporal resolution of 6 hours [67].

\subsubsection{Model Configuration}

Two scenarios (with and without ship emissions) were separately modeled and then compared to identify the evolution of ship-emitted pollutants under the impact of sea breeze circulation. All configurations of the WRF/Chem model were kept consistent for the two scenarios except for the emission inputs. A three-level-nested domain was designed for the modeling system, as shown in Figure 1. Domain 1 covers most of China with a grid resolution of $27 \mathrm{~km}$ (174 rows and 152 columns). Domain 2 covers the Bohai Rim Region with a grid resolution of $9 \mathrm{~km}$ (99 rows and 72 columns). Domain 3 covers Tangshan city, and part of Tianjin and the Bohai Sea, with a grid resolution of $3 \mathrm{~km}$ (75 rows and 81 columns). In the vertical dimension, each domain has 30 vertical layers extending from the surface to the 100-hPa level, with 18 layers within $4 \mathrm{~km}$; the lowest layer has a thickness of 
approximately $40 \mathrm{~m}$. The temporal resolution of the modeling output is adjustable and was set for 1-min resolution in this study. A spin-up period of three days prior to June 29, 2014 was also simulated to minimize the influence of initial conditions. The physical and chemical schemes used in the model are listed in Table 2.

Table 2. WRF/Chem configurations for physical and chemical schemes.

\begin{tabular}{|c|c|c|c|}
\hline Chemical a & d Physics Options & Schemes & Reference \\
\hline \multirow[t]{2}{*}{ Chemical Schemes } & Gas-phase & $\begin{array}{l}\text { The Regional Acid Deposition } \\
\text { Model version } 2 \text { (RMD2) }\end{array}$ & Stockwell et al. [68] \\
\hline & Aerosol & $\begin{array}{l}\text { The Modal Aerosol Dynamics } \\
\text { Model for Europe } \\
\text { (MADE/SORGAM) }\end{array}$ & $\begin{array}{c}\text { Ackermann et al. [69]; Schell } \\
\text { et al. [70] }\end{array}$ \\
\hline \multirow{5}{*}{ Physics Schemes } & Planetary Boundary layer & Yonsei University (YSU) & Hong et al. [71] \\
\hline & Longwave Radiation & $\begin{array}{l}\text { Eta Geophysical Fluid Dynamics } \\
\text { Laboratory (GFDL) }\end{array}$ & Fels and Schwarzkopf [72] \\
\hline & Shortwave Radiation & Goddard & Chou and Suarez [73] \\
\hline & Microphysics & Purdue Lin & Lin et al. [74] \\
\hline & Land Surface Model & Noah & Ek et al. [75] \\
\hline
\end{tabular}

\subsection{Model Evaluation}

Although the performance of the WRF/Chem model has been extensively evaluated in our previous studies $[6,53,55]$ and those of other researchers [76-81], we must nonetheless provide detailed information on the model's performance during the sea breeze episode in this study. Similar evaluation methods to those employed by Chen et al. [6] were applied in the Bohai Rim Region. The simulated results of meteorological factors (e.g., temperature at $2 \mathrm{~m}, \mathrm{~T} 2$; relative humidity at $2 \mathrm{~m}, \mathrm{RH}_{2}$; wind speed at $10 \mathrm{~m}, \mathrm{WS}_{10}$; wind direction at $10 \mathrm{~m}, \mathrm{WD}_{10}$ ) were compared with ground-based meteorological observations that were available every three hours at four sites (Tianjin, Binhai, Tangshan, and Leting), as marked by the black triangle in Figure 1. The meteorological observation data used for the evaluation of model performance were obtained from the Integrated Surface Data (ISD) of National Centers for Environmental Information [82].

Table 3 summarizes the meteorological performance statistics of the model, including the values of mean bias (MB), mean absolute error (MAE), normalized mean bias (NMB), normalized mean error (NME), and the correlative coefficient (R). The correlation coefficient $(\mathrm{R})$ formulation for wind direction is different from the formulations for other scalar quantities due to its vector nature, and follows on from the work of Kwok et al. [83]. In general, the simulation results were in close accordance with the observations, with a high correlation coefficient (R), i.e., 0.72-0.92 (statistically significant at a $95 \%$ confidence level) and relatively low mean absolute error (MAE) values for temperature $\left(1.43-2.38{ }^{\circ} \mathrm{C}\right)$, relative humidity $(8.59-20.73 \%)$, wind speed $(0.65-1.05 \mathrm{~m} / \mathrm{s})$, and wind direction $\left(24.82-30.02^{\circ}\right)$. Similarly, reasonable results of mean bias (MB) were found for temperature $(-0.06$ to $\left.0.82{ }^{\circ} \mathrm{C}\right)$, relative humidity $(-15.18$ to $-1.05 \%$ ), wind speed $(0.32$ to $0.50 \mathrm{~m} / \mathrm{s})$, and wind direction $\left(5.33\right.$ to $\left.8.80^{\circ}\right)$. Certain discrepancies between simulations and observations were within the acceptable ranges proposed by Zhang et al. [84]. The diurnal variations of $\mathrm{RH}_{2}, \mathrm{~T}_{2}$, and the wind field were also generally accurately reproduced by the model.

As one of the primary pollutants emitted by ships, $\mathrm{NO}_{2}$ was selected to investigate the impact of sea breezes on the transport of ship-emitted pollutants. Simulated $\mathrm{NO}_{2}$ on June 29,2014 was compared with averaged surface observations (hourly) in two cities (17 sites in Tianjin and 13 in Tangshan); the surface observations were obtained from the local Environmental Protection Bureaus. As indicated by the $\mathrm{NO}_{2}$ performance statistics summarized in Table 4, the simulated results were reasonably consistent with the observations. Strong correlation coefficients (R) for $\mathrm{NO}_{2}$ were observed, i.e., 0.95 in Tianjin and 0.90 in Tangshan. The value of NMB ranged from $-12.27 \%$ to $-2.32 \%$ (within $\pm 30 \%$ ), which was comparable to other modeling studies [83,84]. The value of NME ranged from $16.61 \%$ to $19.91 \%$, 
and the MFB and MFE ranged from $-13.07 \%$ to $-6.30 \%$ and $13.54 \%$ to $17.98 \%$, respectively. The detail equations of the statistical metrics in this study are as follows [85].

$$
\begin{gathered}
M B=\frac{\sum_{i=1}^{N}\left(C_{m}-C_{o}\right)}{N} \\
M A E=\frac{\sum_{i=1}^{N}\left|C_{m}-C_{o}\right|}{N} \\
N M B=\frac{\sum_{i=1}^{N}\left(C_{m}-C_{o}\right)}{\sum_{i=1}^{n} C_{o}} \\
N M E=\frac{\sum_{i=1}^{N}\left|C_{m}-C_{o}\right|}{\sum_{i=1}^{N} C_{o}} \\
M F B=\frac{1}{N} \sum_{i=1}^{N} \frac{\left(C_{m}-C_{o}\right)}{\left(c_{o}+c_{m} / 2\right)} \\
M F E=\frac{1}{N} \sum_{i=1}^{N} \frac{\left|C_{m}-C_{o}\right|}{\left(C_{o}+C_{m} / 2\right)} \\
R=\frac{\sum_{i=1}^{N}\left(C_{m}-\overline{C_{m}}\right)\left(C_{o}-\overline{C_{o}}\right)}{\sqrt{\sum_{i=1}^{N}\left(C_{m}-\overline{C_{m}}\right)^{2}} \sqrt{\sum_{i=1}^{N}\left(C_{o}-\overline{C_{o}}\right)^{2}}}
\end{gathered}
$$

where:

$C_{m}=$ The model-estimated concentration at hour $i$

$C_{0}=$ The observed concentration at hour $i$

$\overline{C_{m}}=$ The average model-estimated concentration of all hours

$\overline{C_{0}}=$ The average observed concentration of all hours

$N=$ The total numbers of hours for which the simulations are compared against observations

Table 3. Performance statistics for temperature at $2 \mathrm{~m}\left(\mathrm{~T}_{2}\right)$, relative humidity at $2 \mathrm{~m}\left(\mathrm{RH}_{2}\right)$, wind speed at $10 \mathrm{~m}\left(\mathrm{WS}_{10}\right)$, and wind direction at $10 \mathrm{~m}\left(\mathrm{WD}_{10}\right)$ at four sites within the study area.

\begin{tabular}{ccccccc}
\hline Sites & Vars $^{*}$ & $\mathbf{M B}^{\mathbf{a}}$ & $\mathbf{M A E}^{\mathbf{b}}$ & $\mathbf{N M B}^{\mathbf{c}} \mathbf{( \% )}$ & $\mathbf{N M E}^{\mathbf{d}} \mathbf{( \% )}$ & $\mathbf{R}^{\mathbf{e}}$ \\
\hline \multirow{5}{*}{ Tianjin } & $\mathrm{T}_{2}$ & 0.82 & 1.96 & 6.20 & 6.66 & 0.91 \\
& $\mathrm{RH}_{2}$ & -15.18 & 15.18 & -22.63 & 32.63 & 0.82 \\
& $\mathrm{WS}_{10}$ & 0.38 & 0.66 & 15.83 & 27.63 & 0.82 \\
& $\mathrm{WD}_{10}$ & 8.80 & 25.78 & 9.82 & 16.88 & 0.75 \\
& $\mathrm{~T}_{2}$ & -0.23 & 1.73 & -0.77 & 5.76 & 0.92 \\
Binhai & $\mathrm{RH}_{2}$ & -1.05 & 8.59 & -2.63 & 21.61 & 0.85 \\
& $\mathrm{WS}_{10}$ & 0.32 & 0.65 & 11.22 & 22.62 & 0.80 \\
& $\mathrm{WD}_{10}$ & 6.59 & 24.82 & 22.86 & 31.81 & 0.76 \\
& $\mathrm{~T}_{2}$ & 1.01 & 1.43 & 3.60 & 5.10 & 0.92 \\
Langshan & $\mathrm{RH}_{2}$ & -12.06 & 12.06 & -22.45 & 22.45 & 0.84 \\
& $\mathrm{WS}_{10}$ & 0.45 & 0.76 & 12.12 & 34.78 & 0.79 \\
& $\mathrm{WD}_{10}$ & 5.33 & 26.62 & 18.13 & 29.13 & 0.72 \\
& $\mathrm{~T}_{2}$ & -0.06 & 2.38 & -0.22 & 9.31 & 0.91 \\
& $\mathrm{RH}_{2}$ & -6.53 & 20.73 & -11.16 & 38.61 & 0.83 \\
& $\mathrm{WS}_{10}$ & 0.50 & 1.05 & 18.97 & 37.00 & 0.82 \\
& $\mathrm{WD}_{10}$ & 7.92 & 30.02 & 17.91 & 33.74 & 0.79
\end{tabular}

a $\mathrm{MB}$ indicates the mean bias. ${ }^{\mathrm{b}} \mathrm{MAE}$ indicates the mean absolute error. ${ }^{\mathrm{c}} \mathrm{NMB}$ indicates the normalized mean bias. ${ }^{\mathrm{d}}$ NME indicates the normalized mean error. ${ }^{\mathrm{e}} \mathrm{R}$ indicates the Correlative Coefficient. 
Table 4. Performance statistics for $\mathrm{NO}_{2}$ concentrations in 2 cities (17 sites in Tianjin and 13 sites in Tangshan) within the study area.

\begin{tabular}{cccccc}
\hline Sites & $\mathbf{N M B}^{\mathbf{a}} \mathbf{( \% )}$ & $\mathbf{N M E}^{\mathbf{b}} \mathbf{( \% )}$ & $\mathbf{M F B}^{\mathbf{c}} \mathbf{( \% )}$ & $\mathbf{M F E}^{\mathbf{d}} \mathbf{( \% )}$ & $\mathbf{R}^{\mathbf{e}}$ \\
\hline Tianjin & -12.27 & 19.91 & -13.07 & 17.98 & 0.95 \\
Tangshan & -2.32 & 16.61 & -6.30 & 13.54 & 0.90 \\
\hline
\end{tabular}

${ }^{a} \mathrm{NMB}$ indicates the normalized mean bias. ${ }^{\mathrm{b}}$ NME indicates the normalized mean error. ${ }^{\mathrm{c}}$ MFB indicates the Mean Fractional Bias. ${ }^{\mathrm{d}}$ MFE indicates the Mean Fractional Error. ${ }^{\mathrm{e}} \mathrm{R}$ indicates the Correlative Coefficient.

As described above, the simulated values generally agreed with the observations, but certain deviations were still observed between the simulation results and the observational data. These deviations might be explained by the inherent uncertainty of the meteorological input, emission inventory, and the unavoidable deficiencies of the meteorological and the air quality models (e.g., the imperfection of the initial and boundary conditions), as discussed in previous studies [86,87].

\subsection{Identification of the Sea Breeze}

The prime criteria for identifying a sea breeze are generally based on the diurnal reversal of surface wind direction associated with the sea breeze circulation $[88,89]$. In this study, the criteria follows Furberg et al. [89], Cesar et al. [90], and Borne et al. [88], and is summarized as follows: (1) There should be a distinct veering in the surface wind direction from offshore to onshore within a 24 hour period, with brief transition periods occurring between sea and land breeze passages. These periods can be defined by a $30 \mathrm{~min}$. mean wind speed of $<1.5 \mathrm{~m} / \mathrm{s}$ or a sudden change in wind direction [90]. (2) The difference between the daily maximum air temperature over land and sea surface temperature (SST) (referred to as the land-sea temperature contrast) is at least $3^{\circ} \mathrm{C}$. (3) The wind at the $850 \mathrm{hPa}$ pressure level blows offshore during the daytime. (4) There is no precipitation prior to the onset of the sea breeze; then, the temperature reduces and the relative humidity increases significantly after the initiation of the sea breeze. The first criterion, which is considered to be the most important, was used to ensure that the wind was turning from offshore to onshore at the onset of the sea breeze. The second criterion was used to ensure that the physical mechanism driving the sea breeze was active. The third criterion was used to exclude onshore winds that were caused by synoptic forcing [28]. The fourth criterion denotes supplemental features for finding the sea breeze.

\section{Results and Discussion}

\subsection{Synoptic Background}

The development of sea breeze circulation is sensitive to the large-scale synoptic background, which plays an important role in modulating the prevailing wind direction near the surface [91]. Figures 2 and 3 are the weather charts for surface and upper air respectively ( $850 \mathrm{hPa}$ pressure level) on June 29, 2014. At the surface, as shown in Figure 2, the weak pressure gradient and the absence of strong synoptic winds in the study area make possible the development of sea breeze circulation. For upper air, as shown in the $850 \mathrm{hPa}$ pressure level charts at 08:00 and 20:00 local time on June 29, 2014 (Figure 3), a northerly wind blew offshore all day over the study area, which ruled out the possibility of onshore winds that were caused by synoptic forcing $[28,92]$. 

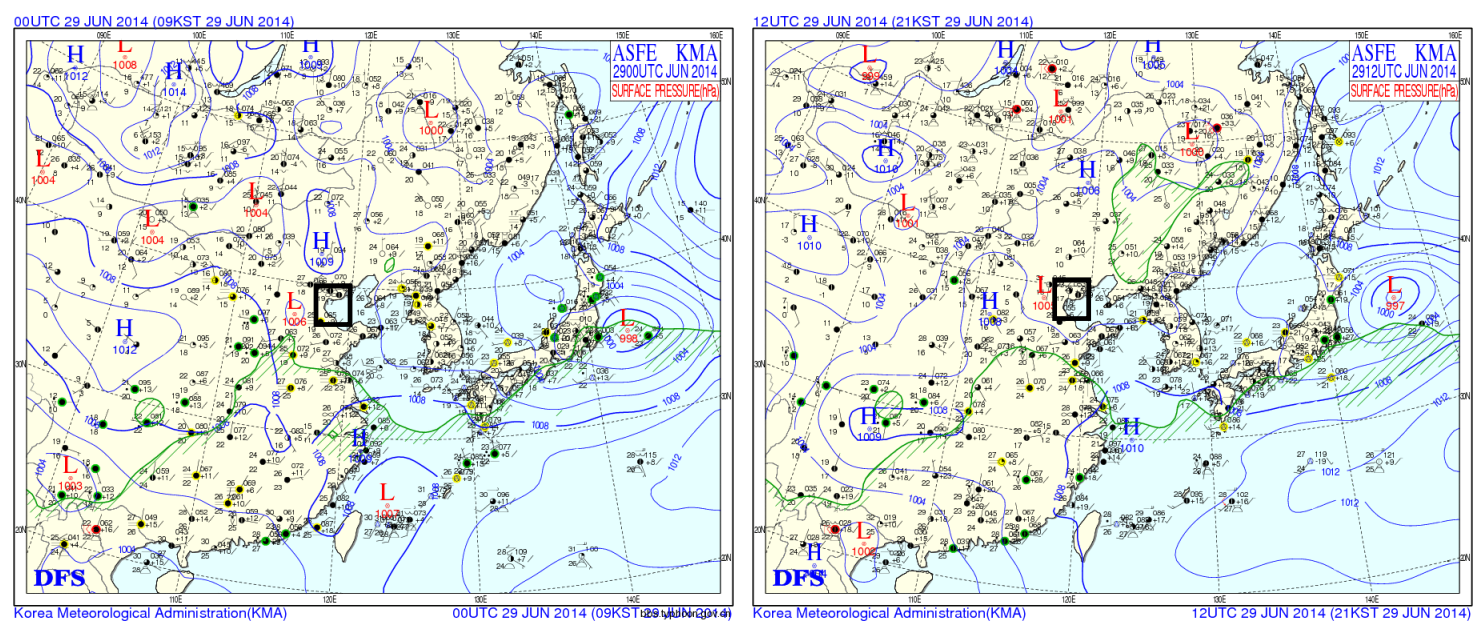

Figure 2. Weather charts at the surface on June 29, 2014 (the location of the study area is indicated by the black rectangle. The charts were obtained from the Korean Meteorological Administration).
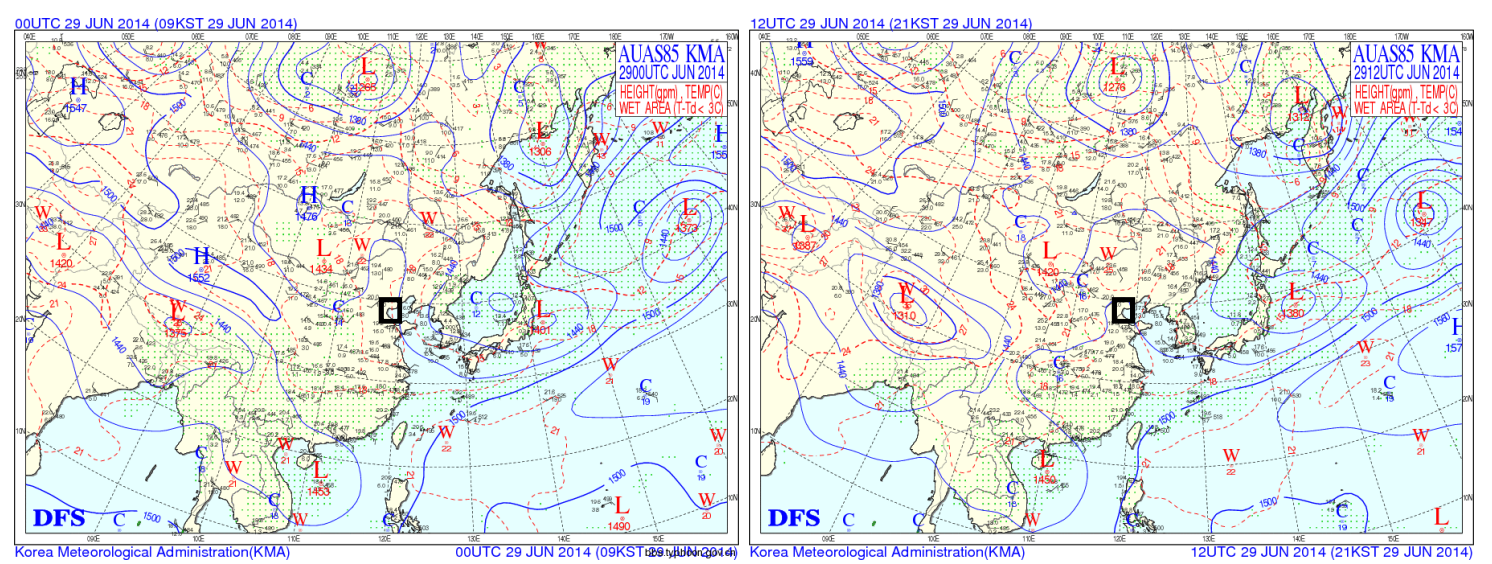

Figure 3. Weather charts at the $850 \mathrm{hPa}$ pressure level on June 29, 2014 (The location of the study area is indicated by the black rectangle. The charts were obtained from the Korean Meteorological Administration).

\subsection{Development of the Sea Breeze Circulation}

The simulated horizontal evolution of the 2-m temperature $\left(\mathrm{T}_{2}\right)$ and relative humidity $\left(\mathrm{RH}_{2}\right)$ overlaid by the surface wind vectors on June 29, 2014 in the Tangshan port area are shown in the left and middle columns of Figure 4, respectively. The right column of Figure 4 shows the vertical cross sections along the black solid line, as depicted in the left columns.

At 8:00, the surface winds were dominated by an offshore flow in the study area, which was consistent with the wind directions in the upper levels, as illustrated in the vertical cross section. In the following hours, the land heated more quickly than the water because of the uneven heating rates, and the land-sea temperature contrast became increasingly sharp with the increase of solar radiation. The thermal contrast created a local-scale pressure gradient force (PGF) directed from sea to land. Around noon, in response to the increase of PGF, the marine air near the surface was driven inland near the land-water boundary on the northeast corner of the study area, and the surface prevailing offshore winds began to be deflected by this landward flow. This change in wind direction marks the beginning of the sea breeze episode; the landward edge of the sea breeze is usually defined as the sea breeze front (SBF) or the convergence zone [32]. At 14:00, with the continued increase in the contrast in temperature between land and water, the onshore winds strengthened at the surface, with its front (SBF) penetrating $\sim 20 \mathrm{~km}$ inland. A vertical circulation developed over the land-water boundary, with a raised head above and immediately behind the SBF, which was created by updrafts within 
both the continental and marine air masses. As the SBF moved inland, the surface temperature in the land area decreased and the relative humidity rose behind it. In the following hours, as the sea breeze became more mature, the SBF moved constantly further inland. Before sunset (19:00, sunset time was 19:43 local time), the sea breeze penetrated more than $100 \mathrm{~km}$ inland, with an evident vertical circulation remaining notable. After sunset (20:00), the synoptic wind strengthened, and the sea breeze circulation weakened gradually due to the decrease in the thermal contrast. Although the onshore flow continued to move inland at the surface in the following hours, the vertical circulation was no longer readily identifiable in the vertical cross section.

\subsection{Impact of Sea Breeze on the Transport of Ship Emissions}

As discussed above, the well-developed sea breeze circulation that occurred on June 29, 2014 significantly influenced the local atmospheric circulation in the study area. It lasted more than ten hours and penetrated over $100 \mathrm{~km}$ inland. The transport and dispersion of air pollutants may have thus been significantly affected by this local circulation, and ship emissions, especially those emitted in ports and near-shore areas, could have been transported far inland by the surface onshore flow, thus aggravating the air pollution in coastal cities. Therefore, it is meaningful to investigate the transport and evolution of the ship-emitted pollutants associated with this circulation.

As one of the primary pollutants emitted by ships, $\mathrm{NO}_{2}$ was used to investigate the impact of sea breezes on the transport of ship-emitted pollutants. Notably, ship-contributed $\mathrm{NO}_{2}$ was estimated by comparing the modeling scenarios with and without ship emissions.

Figure 5 illustrates the horizontal (left column) and vertical (right column) evolution of ship-contributed $\mathrm{NO}_{2}$ overlaid by wind vectors in the study area on June 29,2014 . The modeling results at the surface layer were used for the horizontal analysis, and the vertical cross section along the black solid line, as depicted in the left column of Figure 5, was selected to investigate the vertical evolution of ship-contributed $\mathrm{NO}_{2}$. The reasons we chose the location of this cross section are twofold. In addition to being located in the mid-stream of the onshore flow during most of the sea breeze episode, we also considered that the cross-section crossed Tangshan port and the area's main shipping routes, which may be strongly affected by sea breezes, and therefore, are worthy of investigation.

During the early morning hours, as shown in Figure 5, a northerly wind blew the ship-contributed $\mathrm{NO}_{2}$ that had been brought by the onshore wind the day before out to the sea. This process lasted several hours until 10:00, when nearly all the ship-contributed $\mathrm{NO}_{2}$ on land was swept into the sea. Owing to this conveyance, along with freshly-emitted $\mathrm{NO}_{2}$ in port areas and shipping channels, a region with high shipping $\mathrm{NO}_{2}$ contribution became apparent over the water area. In the vertical dimension, the evolution of the atmospheric boundary layer (ABL) played an important role in the $\mathrm{NO}_{2}$ transport and dispersion of the pollutant. At 08:00, the height of ABL was relatively low on land. Ship-contributed $\mathrm{NO}_{2}$ was trapped at a lower altitude (lower than $\sim 1 \mathrm{~km}$ ) in both the land and sea areas. In the following hours, the ABL developed rapidly and extended to $\sim 2 \mathrm{~km}$ above the ground on land at 10:00. Unlike the situation at 08:00, the ship-contributed $\mathrm{NO}_{2}$ was dispersed to a much higher altitude due to the lifting of the ABL. 


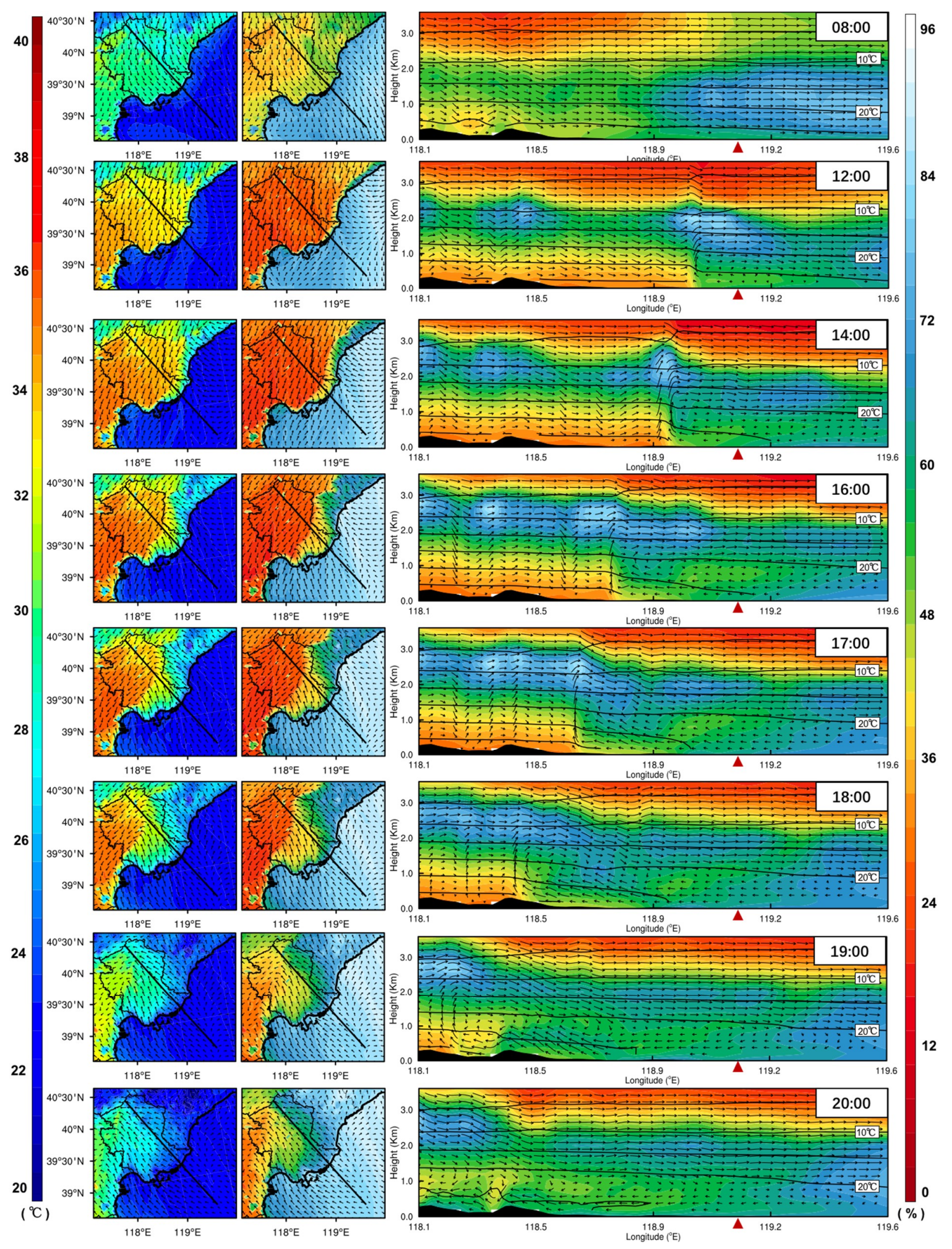

Figure 4. The simulated horizontal evolution of 2-m temperature $\left(\mathrm{T}_{2}\right)$ (the left column), 2-m relative humidity $\left(\mathrm{RH}_{2}\right)$ (the middle column) overlaid by the surface wind vectors, and the vertical cross sections of simulated relative humidity (the right column) overlaid by the temperature contours and wind vectors. The location of the cross section is marked by the black lines in the figures in the left and middle columns. The red triangles in the right column indicate the location of the sea-land boundary. Note that the vertical velocity is multiplied by a factor of 20 when plotting the wind vectors. 


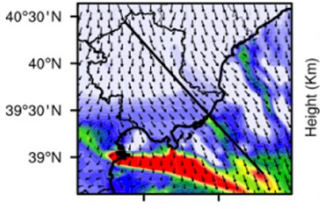

$118^{\circ} \mathrm{E} \quad 119^{\circ} \mathrm{E}$

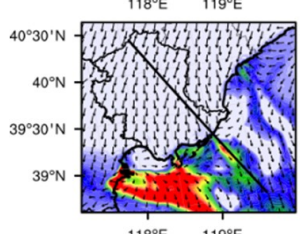

$118^{\circ} \mathrm{E}$

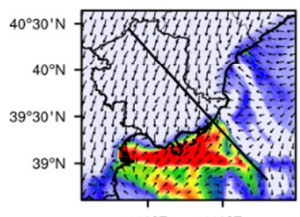

$118^{\circ} \mathrm{E} \quad 119^{\circ} \mathrm{E}$

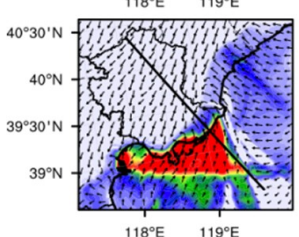

$118^{\circ} \mathrm{E} \quad 119^{\circ} \mathrm{E}$

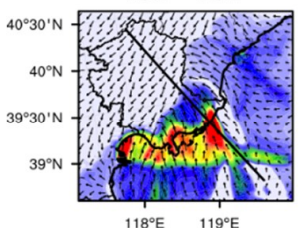

$118^{\circ} \mathrm{E} \quad 119^{\circ} \mathrm{E}$

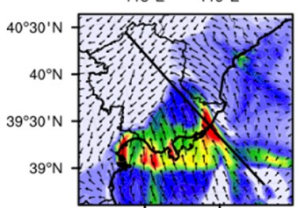

$118^{\circ} \mathrm{E} \quad 119^{\circ} \mathrm{E}$

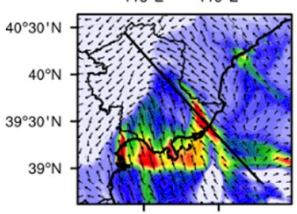

$118^{\circ} \mathrm{E} \quad 119^{\circ} \mathrm{E}$

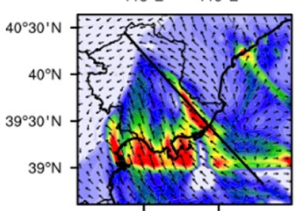

$118^{\circ} \mathrm{E} \quad 119^{\circ} \mathrm{E}$

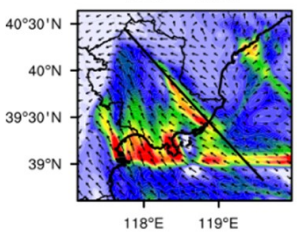

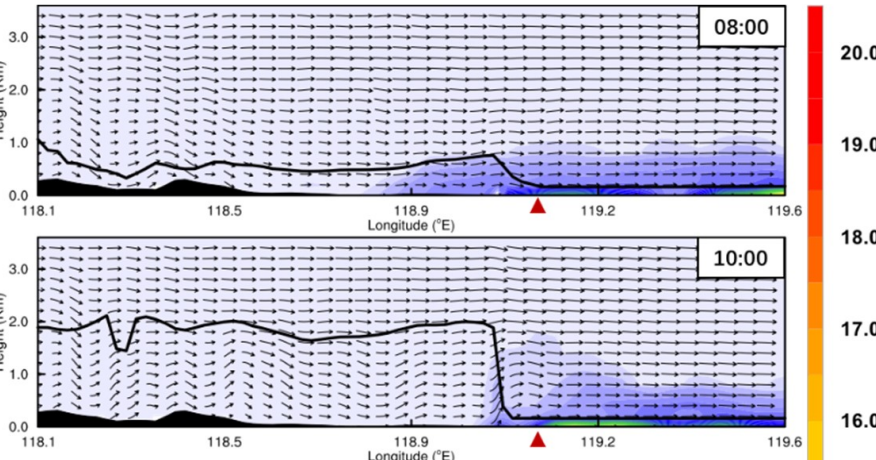
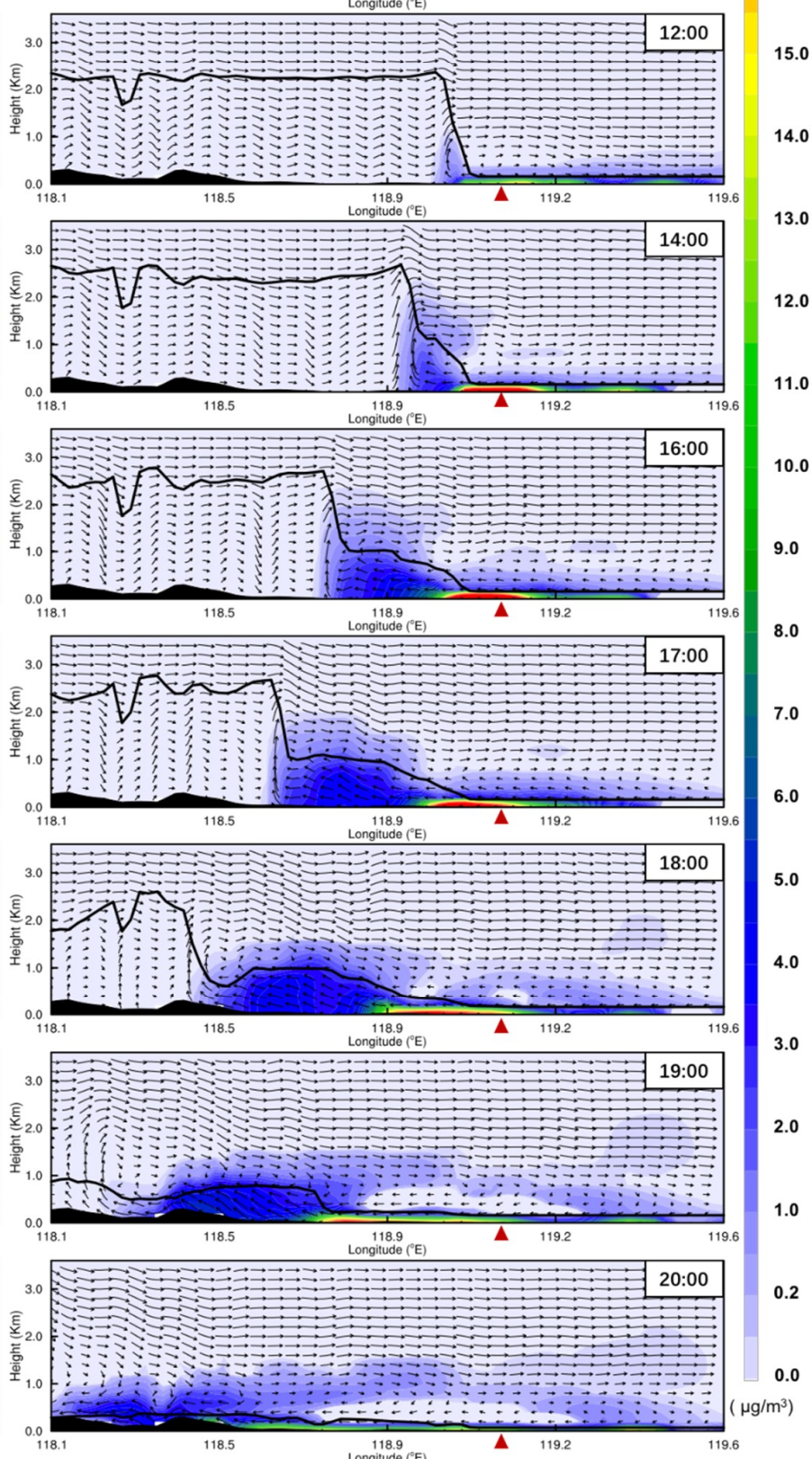

Figure 5. The horizontal (left column) and vertical (right column) axes represent the evolution of ship-contributed $\mathrm{NO}_{2}$ overlaid by wind vectors. The black lines in the left column indicate the locations of the vertical cross sections shown in the right column. The black curves in the right column show the top of the atmospheric boundary layer (obtained from the model output for each grid along the vertical cross section). The red triangles in the right column indicate the location of the sea-land boundary. 
Around midday, at the sea surface, the prevailing offshore winds from previous hours changed to shoreward with the increasing land-sea temperature contrast. Ship-emitted $\mathrm{NO}_{2}$ was transported landward by this onshore flow. The pollutant penetrated inland at the northeastern and southwestern part of the study area, but was blocked along the Tangshan coastline in the center of the study area. This result was chiefly due to the relatively small angle (less than 90 degree) between the onshore flow and the prevailing wind in the former case, while the opposite flow directions occurred in the latter case. Vertically, there were three evident differences compared with the situation at 10:00. First, the ABL height increased by $\sim 200$ meters on land while staying the same on the sea. There was a notably sharp decrease (i.e., large gradient) of the ABL height near the water-land boundary at 10:00. At 12:00, however, the situation changed and the gradient of the ABL height over this area decreased. This dynamic may be explained by the cooling effect of the sea breeze, which brought the cool marine air to the hot land surface and decreased the temperature within the ABL. As a result, the vertical turbulence within the ABL was reduced, and the ABL height was lowered. Second, the ship-contributed $\mathrm{NO}_{2}$ decreased dramatically in the upper air on the sea. By examining the wind vectors over this area at 10:00 and 12:00, it could be inferred that the downward wind vectors may bring the pollutant to the lower level, and the seaward prevailing wind may eventually transport it out of the study area. Third, a sea breeze circulation cell began to form near the land-water boundary where onshore flows appeared at low levels (below $\sim 200 \mathrm{~m}$ ), and returning offshore flows appeared on the upper (around $300 \mathrm{~m}-1 \mathrm{~km}$ ) levels. Ship-emitted $\mathrm{NO}_{2}$ was transported from the surface level to higher levels with the upward motion of the sea breeze near the land-water boundary, but was limited to below $\sim 1 \mathrm{~km}$. The ship-contributed $\mathrm{NO}_{2}$ on the sea was mostly limited below the ABL, but areas with high concentrations were closer to the shore than they were previously.

At 14:00, horizontally, the sea breeze front (SBF) moved further landward in the northeastern and southwestern parts of the study area. Under the $\mathrm{SBF}^{\prime}$ s influence, ship-emitted $\mathrm{NO}_{2}$ was transported inland over these areas by $\sim 25 \mathrm{~km}$, but with little change in the concentration. In the center of the study area along the Tangshan coastline, the increasing land-sea temperature contrast, due to the continuous solar radiation, enabled the SBF's movement against the prevailing wind and penetrated inland. Ship-emitted $\mathrm{NO}_{2}$ was transported to the land by the sea breeze, but only advanced $\sim 20 \mathrm{~km}$ from the coastline. Areas with high $\mathrm{NO}_{2}$ were also found on the landward side of the water-land boundary, i.e., were not only confined to the sea. In the vertical dimension, the ABL deepened further, reaching $\sim 2.5 \mathrm{~km}$ on the land and with little change on the sea. Compared with the situation at 12:00, the ABL height between the SBF and the coastline further decreased with the advance of the SBF. At the leading edge of the sea breeze, the upward motion of air lifted the ABL top; the ship-emitted $\mathrm{NO}_{2}$ was transported from the surface to higher levels $(\sim 2.5 \mathrm{~km})$ by this updraft, and was brought back to the sea by the returning flow.

From 16:00-18:00, as the sea breeze became more mature, and the SBF progressed further inland in the northeastern and southwestern parts of the study area. Along with the onshore breeze, ship-emitted $\mathrm{NO}_{2}$ was transported $\sim 80 \mathrm{~km}$ inland in the northeast at 18:00. In the southwest, the penetration was as far as $40 \mathrm{~km}$ at 16:00, but was restricted within the same distance at 17:00 and 18:00. In the center of the study area along the Tangshan coastline, the sea breeze deflected the northeast prevailing wind over land and penetrated further landward, expanding the impact of ship emissions to as far as $80 \mathrm{~km}$ inland at 18:00. Vertically, the ABL height over the inland area that was not yet affected by the sea breeze varied minimally compared with the situation at 14:00, while evident expansion was observed in the range between the SBF and the coastline, where the ABL height was lowered due to the cooling effect of the sea breeze. Ship-emitted $\mathrm{NO}_{2}$ that was transported by the onshore wind near the surface was trapped within this lowered boundary layer, and its concentration was thus increased.

At 19:00 and 20:00 (the time around sunset, i.e., 19:43), the horizontal dispersion pattern of the ship-emitted $\mathrm{NO}_{2}$ was similar to that of the previous few hours, excepting that the pollutant was transported $\sim 100 \mathrm{~km}$ inland due to the further penetration of the sea breeze. In the vertical dimension, however, an evident change was observed before and after sunset. Before sunset (19:00), the height of 
the ABL was significantly lowered to $~ 500-700$ meters, with a weakening of vertical mixing due to the reduction in incoming solar radiation levels. An evident sea breeze circulation could still be found at the time, and the SBF still reached more than $100 \mathrm{~km}$ inland. Along with the sea breeze, part of the ship-emitted $\mathrm{NO}_{2}$ traversed hills and moved further inland. Meanwhile, due to the blocking effect of the high terrain and the lowering of the $\mathrm{ABL}$, increasing amounts of $\mathrm{NO}_{2}$ began to accumulate in the plain area in front of the hill. At 20:00, vertical sea breeze circulation was not notable. The ABL height dropped sharply to below $~ 300$ meters as the sun set and evolved into the nighttime stable boundary layer due to the absence of thermal forcing. The $\mathrm{NO}_{2}$ was restricted within this shallow nocturnal mixed layer, which favored the accumulation of pollutants. A high $\mathrm{NO}_{2}$ concentration (over $10 \mu \mathrm{g} / \mathrm{m}^{3}$ ) was thus witnessed in the plain area in front of the hill. In the following hours, the onshore flow could still be observed owing to inertia; ship emissions were still being transported landward, thereby lowering the air quality in the coastal areas until midnight.

To further investigate the overall impact of the sea breeze on the transport of ship emissions, time-averaged wind vectors and ship contributions to $\mathrm{NO}_{2}$ from the beginning to the end of the sea breeze episode were calculated. Figure $6 \mathrm{a}, \mathrm{b}$ shows the averaged $\mathrm{NO}_{2}$ concentration at ground level overlaid by the averaged 10-m wind vectors during the period from 12:00 to 24:00 for the case of no ship emissions and with ship emissions, respectively. By comparing Figure $6 \mathrm{a}, \mathrm{b}$, we can get the ship-contributed $\mathrm{NO}_{2}$, as shown in Figure $6 \mathrm{c}\left(\mu \mathrm{g} / \mathrm{m}^{3}\right.$, i.e., with - without ships) and $6 \mathrm{~d}$ (\%, (with without ships)/with ships)). Further investigation of the variation in the averaged contribution of ship emissions to $\mathrm{NO}_{2}$ with inland distance from the coastline to the line depicted in Figure 6 is presented in Figure 7. It was found that although the ship-emitted pollutants could be transported far inland with the sea breeze, the contribution of ship emissions to $\mathrm{NO}_{2}$ levels showed a downward trend as the distance from the coastline increased. The steepest decline was found in the coastal area, decreasing from more than $36 \mu \mathrm{g} / \mathrm{m}^{3}$ (80 \%) near the coastline to $10 \mu \mathrm{g} / \mathrm{m}^{3}$ (30\%) $15 \mathrm{~km}$ inland. As the inland distance increases (from $20-100 \mathrm{~km}$ inland), the drop tends to be gentle.
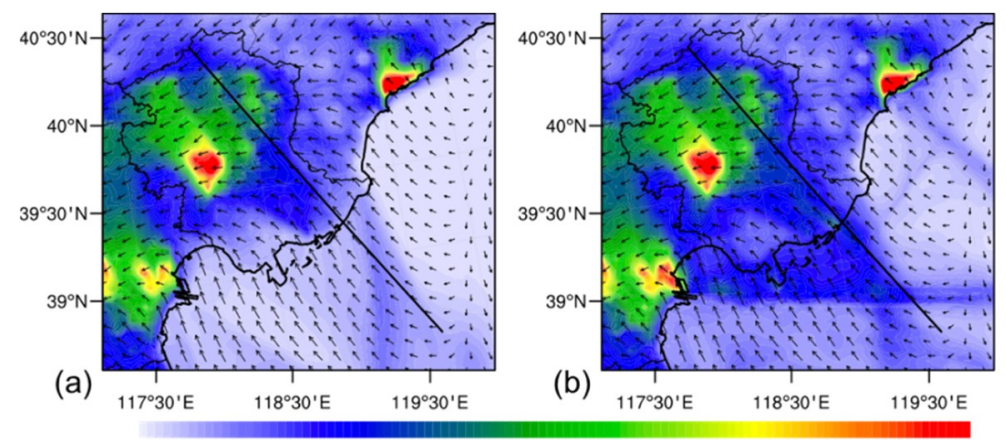

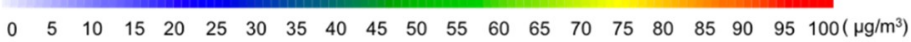
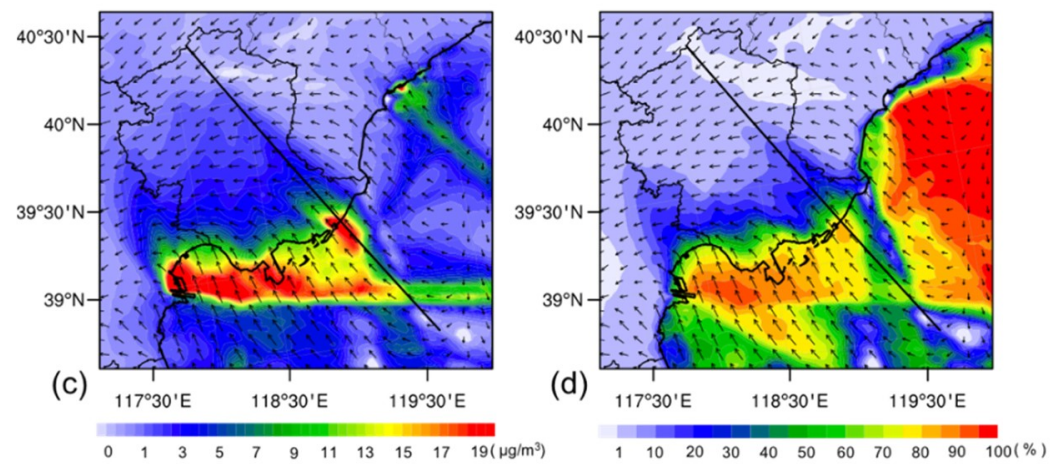

Figure 6. Average $\mathrm{NO}_{2}$ concentration $\left(\mu \mathrm{g} / \mathrm{m}^{3}\right)$ for the case of no ship emissions (a), case of with ship emissions (b), average ship contribution to $\mathrm{NO}_{2}$ in $\mu \mathrm{g} / \mathrm{m}^{3}$ (with - without ships) (c) and in \% ((with without ships)/with ships)) (d) at ground level overlaid by the averaged 10-m wind vectors during the period from 12:00 to 24:00. 


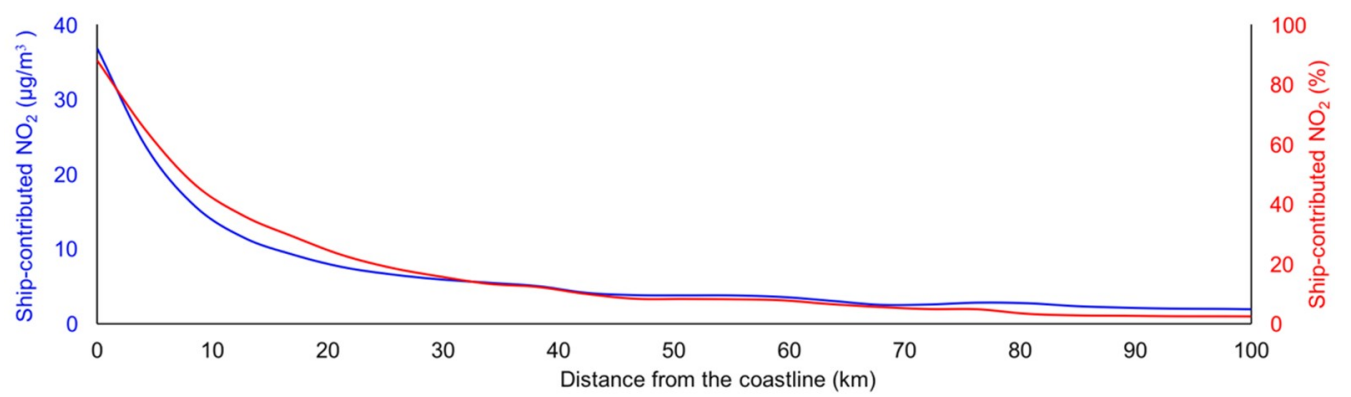

Figure 7. Variation of the averaged ship-contributed $\mathrm{NO}_{2}$ in $\mu \mathrm{g} / \mathrm{m}^{3}$ (blue curve) and in \% (red curve) during the period from 12:00 to 24:00 at ground level with the distance from the coastline to inland along the black line depicted in Figure 6.

\section{Conclusions}

In this study, the WRF/Chem model was employed to investigate the influence of sea breeze circulation on the transport and evolution of ship emissions during a sea breeze episode on 29 June, 2014 in Tangshan port, China. As one of the primary pollutants emitted by ships, $\mathrm{NO}_{2}$ was selected as the target pollutant for investigation. The results indicate that the transport and dispersion of ship-emitted $\mathrm{NO}_{2}$ was significantly affected by the sea breeze circulation, which lasted more than 10 hours. Although the onset of the sea breeze was delayed to nearly midday due to the offshore synoptic winds, ship-emitted $\mathrm{NO}_{2}$ could be transported inland by more than $100 \mathrm{~km}$ due to the penetration of the sea breeze. Further investigation of the averaged concentration of ship-contributed $\mathrm{NO}_{2}$ at ground level during the episode from the beginning of the sea breeze (12:00) to the end (24:00) showed that although ship-emitted pollutants could be transported far inland with the sea breeze, the contribution of ship emissions to $\mathrm{NO}_{2}$ showed a downward trend as the distance from the coastline increased. The steepest decline was found in the coastal area where the ship-contributed $\mathrm{NO}_{2}$ decreased from more than $36 \mu \mathrm{g} / \mathrm{m}^{3}$ (80\%) near the coastline to $\sim 10 \mu \mathrm{g} / \mathrm{m}^{3}(30 \%) 15 \mathrm{~km}$ inland. As the distance inland increases (from 20-100 km inland), the drop tended to be gentle. In the vertical dimension, the height of the ABL in the coastal regions was associated closely with the advection of the sea breeze. The ABL height on the sea was low throughout the day, which limited the vertical dispersion of ship emissions, and most of the pollutants were transported shoreward by the sea breeze within this shallow ABL. The ABL height was lowered in the region between the coastline and SBF due to the cooling effect of the sea breeze, which brought cool marine air to the hot land surface and decreased the temperature within the ABL. The ship-contributed $\mathrm{NO}_{2}$ was mostly trapped within this shallow ABL, and the concentration increased.

Author Contributions: Methodology, D.C.; Validation, X.G., Y.Z. and J.L.; Formal Analysis, F.S.; Investigation, F.S.; Resources, Y.L.; Data Curation, Y.L.; Writing-Original Draft Preparation, F.S.; Writing-Review \& Editing, D.C.; Visualization, F.S.; Supervision, X.F.

Funding: This research was funded by National Natural Science Foundation of China (No. 51978011 \& 51578017).

Acknowledgments: The authors are grateful to the anonymous reviewers for their insightful comments.

Conflicts of Interest: The authors declare no conflict of interest.

\section{References}

1. Feng, J.; Zhang, Y.; Li, S.; Mao, J.; Patton, A.P.; Zhou, Y.; Ma, W.; Liu, C.; Kan, H.; Huang, C.; et al. The influence of spatiality on shipping emissions, air quality and potential human exposure in the Yangtze River Delta/Shanghai, China. Atmos. Chem. Phys. 2019, 19, 6167-6183. [CrossRef]

2. Chen, D.; Tian, X.; Lang, J.; Zhou, Y.; Li, Y.; Guo, X.; Wang, W.; Liu, B. The impact of ship emissions on $\mathrm{PM}_{2.5}$ and the deposition of nitrogen and sulfur in Yangtze River Delta, China. Sci. Total Environ. 2019, 649, 1609-1619. [CrossRef] 
3. Murena, F.; Mocerino, L.; Quaranta, F.; Toscano, D. Impact on air quality of cruise ship emissions in Naples, Italy. Atmos. Environ. 2018, 187, 70-83. [CrossRef]

4. Liu, H.; Meng, Z.H.; Shang, Y.; Lv, Z.F.; Jin, X.X.; Fu, M.L.; He, K.B. Shipping emission forecasts and cost-benefit analysis of China ports and key regions' control. Environ. Pollut. 2018, 236, 49-59. [CrossRef]

5. Liu, H.; Jin, X.; Wu, L.; Wang, X.; Fu, M.; Lv, Z.; Morawska, L.; Huang, F.; He, K. The impact of marine shipping and its DECA control on air quality in the Pearl River Delta, China. Sci. Total Environ. 2018, 625, 1476-1485. [CrossRef]

6. Chen, D.; Zhao, N.; Lang, J.; Zhou, Y.; Wang, X.; Li, Y.; Zhao, Y.; Guo, X. Contribution of ship emissions to the concentration of $\mathrm{PM}_{2.5}$ : A comprehensive study using AIS data and WRF/Chem model in Bohai Rim Region, China. Sci. Total Environ. 2018, 610-611, 1476-1486. [CrossRef]

7. Zhang, Y.; Yang, X.; Brown, R.; Yang, L.P.; Morawska, L.; Ristovski, Z.; Fu, Q.Y.; Huang, C. Shipping emissions and their impacts on air quality in China. Sci. Total Environ. 2017, 581, 186-198. [CrossRef]

8. Zhang, Y.; Gu, J.; Wang, W.; Peng, Y.; Wu, X.; Feng, X. Inland port vessel emissions inventory based on Ship Traffic Emission Assessment Model-Automatic Identification System. Adv. Mech. Eng. 2017, 9, 1687814017712878. [CrossRef]

9. Liu, Z.; Lu, X.; Feng, J.; Fan, Q.; Zhang, Y.; Yang, X. Influence of Ship Emissions on Urban Air Quality: A Comprehensive Study Using Highly Time-Resolved Online Measurements and Numerical Simulation in Shanghai. Environ. Sci. Technol. 2017, 51, 202-211. [CrossRef]

10. Jeong, J.-H.; Shon, Z.-H.; Kang, M.; Song, S.-K.; Kim, Y.-K.; Park, J.; Kim, H. Comparison of source apportionment of $\mathrm{PM}_{2.5}$ using receptor models in the main hub port city of East Asia: Busan. Atmos. Environ. 2017, 148, 115-127. [CrossRef]

11. Becagli, S.; Anello, F.; Bommarito, C.; Cassola, F.; Calzolai, G.; Di Iorio, T.; di Sarra, A.; Gómez-Amo, J.-L.; Lucarelli, F.; Marconi, M.; et al. Constraining the ship contribution to the aerosol of the central Mediterranean. Atmos. Chem. Phys. 2017, 17, 2067-2084. [CrossRef]

12. Yang, M.; Bell, T.G.; Hopkins, F.E.; Smyth, T.J. Attribution of atmospheric sulfur dioxide over the English Channel to dimethyl sulfide and changing ship emissions. Atmos. Chem. Phys. 2016, 16, 4771-4783. [CrossRef]

13. Liu, H.; Fu, M.; Jin, X.; Shang, Y.; Shindell, D.; Faluvegi, G.; Shindell, C.; He, K. Health and climate impacts of ocean-going vessels in East Asia. Nat. Clim. Chang. 2016. [CrossRef]

14. Fan, Q.; Zhang, Y.; Ma, W.; Ma, H.; Feng, J.; Yu, Q.; Yang, X.; Ng, S.K.W.; Fu, Q.; Chen, L. Spatial and seasonal dynamics of ship emissions over the Yangtze River Delta and East China Sea and their potential environmental influence. Environ. Sci. Technol. 2016, 50, 1322-1329. [CrossRef]

15. Aksoyoglu, S.; Baltensperger, U.; Prévôt, A.S.H. Contribution of ship emissions to the concentration and deposition of air pollutants in Europe. Atmos. Chem. Phys. 2016, 16, 1895-1906. [CrossRef]

16. Viana, M.; Fann, N.; Tobias, A.; Querol, X.; Rojas-Rueda, D.; Plaza, A.; Aynos, G.; Conde, J.A.; Fernandez, L.; Fernandez, C. Environmental and health benefits from designating the Marmara Sea and the Turkish Straits as an emission control area (ECA). Environ. Sci. Technol. 2015, 49, 3304-3313. [CrossRef]

17. Zhao, M.; Zhang, Y.; Ma, W.; Fu, Q.; Yang, X.; Li, C.; Zhou, B.; Yu, Q.; Chen, L. Characteristics and ship traffic source identification of air pollutants in China's largest port. Atmos. Environ. 2013, 64, 277-286. [CrossRef]

18. Corbett, J.J. Global sulphur emissions inventories for ocean-going ships and their impact in global chemical transport models. J. Geophys. Res. Atmos. 1999, 104, 3457-3470. [CrossRef]

19. Lv, Z.; Liu, H.; Ying, Q.; Fu, M.; Meng, Z.; Wang, Y.; Wei, W.; Gong, H.; He, K. Impacts of shipping emissions on $\mathrm{PM}_{2.5}$ pollution in China. Atmos. Chem. Phys. 2018, 18, 15811-15824. [CrossRef]

20. Yau, P.S.; Lee, S.C.; Corbett, J.J.; Wang, C.; Cheng, Y.; Ho, K.F. Estimation of exhaust emission from ocean-going vessels in HongKong. Sci. Total Environ. 2012, 431, 299-306. [CrossRef]

21. Dore, A.; Vieno, M.; Tang, Y.; Dragosits, U.; Dosio, A.; Weston, K.; Sutton, M. Modelling the atmospheric transport and deposition of sulphur and nitrogen over the United Kingdom and assessment of the influence of $\mathrm{SO}_{2}$ emissions from international shipping. Atmos. Environ. 2007, 41, 2355-2367. [CrossRef]

22. Corbett, J.J.; Winebrake, J.J.; Green, E.H.; Kasibhatla, P.; Eyring, V.; Lauer, A. Mortality from Ship Emissions: A Global Assessment. Environ. Sci. Technol. 2007, 41, 8512-8518. [CrossRef]

23. Masselink, G.; Pattiaratchi, C.B. The effect of sea breeze on beach morphology, surf zone hydrodynamics and sediment resuspension. Mar. Geol. 1998, 146, 115-135. [CrossRef] 
24. Huang, M.; Gao, Z.; Miao, S.; Xu, X. Characteristics of sea breezes over the Jiangsu coastal area, China. Int. J. Climatol. 2016, 36, 3908-3916. [CrossRef]

25. Zhang, Z.Z.; Cao, C.X.; Song, Y.; Kang, L.; Cai, X.H. Statistical charactristics and numberical simulation of sea-land breezes in Hainan island. J. Trop. Meteorol. 2014, 20, 267-278.

26. Rani, S.I.; Ramachandran, R.; Subrahamanyam, D.B.; Alappattu, D.P.; Kunhikrishnan, P.K. Characterization of sea/land breeze circulation along the west coast of Indian sub-continent during pre-monsoon season. Atmos. Res. 2010, 95, 367-378. [CrossRef]

27. Eager, R.E.; Raman, S.; Wootten, A.; Westphal, D.L.; Reid, J.S.; Al Mandoos, A. A climatological study of the sea and land breezes in the Arabian Gulf region. J. Geophys. Res.-Atmos. 2008, 113. [CrossRef]

28. Papanastasiou, D.K.; Melas, D. Climatology and impact on air quality of sea breeze in an urban coastal environment. Int. J. Climatol. 2009, 29, 305-315. [CrossRef]

29. Yu, E.; Chen, B.; Bai, Y. Land and sea breezes in the weatern Bohai wan. Acta. Meteorol. 1987, 45, 379-381.

30. Mavrakou, T.; Philippopoulos, K.; Deligiorgi, D. The impact of sea breeze under different synoptic patterns on air pollution within Athens basin. Sci. Total Environ. 2012, 433, 31-43. [CrossRef]

31. Bouchlaghem, K.; Ben Mansour, F.; Elouragini, S. Impact of a sea breeze event on air pollution at the Eastern Tunisian Coast. Atmos. Res. 2007, 86, 162-172. [CrossRef]

32. Miller, S.T.K.; Keim, B.D.; Talbot, R.W.; Mao, H. Sea breeze: Structure, forecasting, and impacts. Rev. Geophys. 2003, 41, 31. [CrossRef]

33. Grossi, P.; Thunis, P.; Martilli, A.; Clappier, A. Effect of sea breeze on air pollution in the Greater Athens Area. Part II: Analysis of different emission scenarios. J. Appl. Meteorol. 2000, 39, 563-575. [CrossRef]

34. Clappier, A.; Martilli, A.; Grossi, P.; Thunis, P.; Pasi, F.; Krueger, B.C.; Calpini, B.; Graziani, G.; van den Bergh, H. Effect of sea breeze on air pollution in the Greater Athens Area. Part I: Numerical simulations and field observations. J. Appl. Meteorol. 2000, 39, 546-562. [CrossRef]

35. Kolev, I.; Parvanov, O.; Kaprielov, B.; Donev, E.; Ivanov, D. Lidar observations of sea-breeze and land-breeze aerosol structure on the Black Sea. J. Appl. Meteorol. 1998, 37, 982-995. [CrossRef]

36. Camps, J.; Massons, J.; Soler, M.R. Numerical modelling of pollutant dispersion in sea breeze conditions. Ann. Geophys. Atmos. Hydrospheres Space Sci. 1996, 14, 665-677. [CrossRef]

37. Rong Lu, R.P.T. Air pollutant transport in a coastal environment-II 3 dimensional simulations over los angeles basin. Atmos. Environ. 1995, 29, 1499-1518.

38. Nester, K. Influence of sea breeze flows on air pollution over the attica peninsula. Atmos. Environ. 1995, 29, 3655-3670. [CrossRef]

39. Physick, W.L.; Abbs, D.J. Flow and plume dispersion in a coastal valley. J. Appl. Meteorol. 1992, 31, 64-73. [CrossRef]

40. Tsai, H.H.; Yuan, C.S.; Hung, C.H.; Lin, C.; Lin, Y.C. Influence of Sea-Land Breezes on the Tempospatial Distribution of Atmospheric Aerosols over Coastal Region. J. Air Waste Manag. Assoc. 2011, 61, 358-376. [CrossRef]

41. Abbs, D.J.; Physick, W.L. Sea-breeze observations and modelling: A review. Aust. Meteorol. Mag. 1992, 41, 7-19.

42. Levy, I.; Mahrer, Y.; Dayan, U. Coastal and synoptic recirculation affecting air pollutants dispersion: A numerical study. Atmos. Environ. 2009, 43, 1991-1999. [CrossRef]

43. Boyouk, N.; Leon, J.F.; Delbarre, H.; Augustin, P.; Fourmentin, M. Impact of sea breeze on vertical structure of aerosol optical properties in Dunkerque, France. Atmos. Res. 2011, 101, 902-910. [CrossRef]

44. Lin, W.S.; Wang, A.Y.; Wu, C.S.; Kun, F.S.; Ku, C.M. A case modeling of sea-land breeze in Macao and its neighborhood. Adv. Atmos. Sci. 2001, 18, 1231-1240.

45. Prabha, T.; Venkatesan, R.; Mursch-Radlgruber, E.; Rengarajan, G.; Jayanthi, N. Thermal internal boundary layer characteristics at a tropical coastal site as observed by a mini-SODAR under varying synoptic conditions. J. Earth Syst. Sci. 2002, 111, 63-77. [CrossRef]

46. Srinivas, C.V. Sensitivity of mesoscale simulations of land-sea breeze to boundary layer turbulence parameterization. Atmos. Environ. 2007, 41, 2534-2548. [CrossRef]

47. Gangoiti, G.; Alonso, M.; Navazo, M.; Albizuri, A.; Perez-Landa, G.; Matabuena, M.; Valdenebro, V.; Maruri, M.; Garcia, J.; Millan, M.A. Regional transport of pollutants over the Bay of Biscay: Analysis of an ozone episode under a blocking anticyclone in west central Europe. Atmos. Environ. 2002, 36, 21349-21361. [CrossRef] 
48. Li, C.; Yuan, Z.; Ou, J.; Fan, X.; Ye, S.; Xiao, T.; Shi, Y.; Huang, Z.; Ng, S.K.; Zhong, Z.; et al. An AIS-based high-resolution ship emission inventory and its uncertainty in Pearl River Delta region, China. Sci. Total Environ. 2016, 573, 1-10. [CrossRef]

49. Chen, D.; Zhao, Y.; Nelson, P.; Li, Y.; Wang, X.; Zhou, Y.; Lang, J.; Guo, X. Estimating ship emissions based on AIS data for port of Tianjin, China. Atmos. Environ. 2016, 145, 10-18. [CrossRef]

50. Corbett, J.J.; Fischbeck, P.S.; Pandis, S.N. Global nitrogen and sulfur inventories for oceangoing ships. J. Geophys. Res.-Atmos. 1999, 104, 3457-3470. [CrossRef]

51. Eyring, V.; Isaksen, I.; Berntsen, T.; Collins, W.; Corbett, J.J.; Endresen, O.; Grainger, R.G.; Moldanova, J.; Schlager, H.; Stevenson, D.S. Transport impacts on atmosphere and climate: Shipping. Atmos. Environ. 2010, 44, 4735-4771. [CrossRef]

52. Eyring, V.; Kohler, H.W.; van Aardenne, J.; Lauer, A. Emissions from international shipping: 1 . The last 50 years. J. Geophys. Res. Atmos. 2005, 110, 12. [CrossRef]

53. Chen, D.; Zhang, Y.; Lang, J.; Ying, Z.; Li, Y.; Guo, X.; Wang, W.; Liu, B. Evaluation of different control measures in 2014 to mitigate the impact of ship emissions on air quality in the Pearl River Delta, China. Atmos. Environ. 2019, 216, 116911. [CrossRef]

54. Tao, J.; Zhang, L.; Cao, J.; Zhong, L.; Chen, D.; Yang, Y.; Chen, D.; Chen, L.; Zhang, Z.; Wu, Y.; et al. Source apportionment of $\mathrm{PM}_{2.5}$ at urban and suburban areas of the Pearl River Delta region, south China With emphasis on ship emissions. Sci. Total Environ. 2017, 574, 1559-1570. [CrossRef]

55. Chen, D.; Wang, X.; Nelson, P.; Li, Y.; Zhao, N.; Zhao, Y.; Lang, J.; Zhou, Y.; Guo, X. Ship emission inventory and its impact on the $\mathrm{PM}_{2.5}$ air pollution in Qingdao Port, North China. Atmos. Environ. 2017, 166, 351-361. [CrossRef]

56. Contini, D.; Gambaro, A.; Donateo, A.; Cescon, P.; Cesari, D.; Merico, E.; Belosi, F.; Citron, M. Inter-annual trend of the primary contribution of ship emissions to $\mathrm{PM}_{2.5}$ concentrations in Venice (Italy): Efficiency of emissions mitigation strategies. Atmos. Environ. 2015, 102, 183-190. [CrossRef]

57. Tao, L.; Fairley, D.; Kleeman, M.J.; Harley, R.A. Effects of switching to lower sulfur marine fuel oil on air quality in the San Francisco Bay area. Environ. Sci. Technol. 2013, 47, 10171-10178. [CrossRef]

58. MOT of China. Available online: http://xxgk.mot.gov.cn/jigou/zhghs/201905/t20190513_3198921.html (accessed on 20 October 2019).

59. Grell, G.; Peckham, S.; Schmitz, R.; McKeen, S.; Frost, G.; Skamarock, W.; Eder, B. Fully coupled “online" Chemistry within the WRF model. Atmos. Environ. 2005, 39, 6957-6975. [CrossRef]

60. Chen, D.; Wang, X.; Li, Y.; Lang, J.; Zhou, Y.; Guo, X.; Zhao, Y. High-spatiotemporal-resolution ship emission inventory of China based on AIS data in 2014. Sci. Total Environ. 2017, 609, 776-787. [CrossRef]

61. Liu, F.; Zhang, Q.; Tong, D.; Zheng, B.; Li, M.; Huo, H.; He, K. High-resolution inventory of technologies, activities, and emissions of coal-red power plants in China from 1990 to 2010. Atmos. Chem. Phys. 2015, 15, 13299-13317. [CrossRef]

62. Zheng, B.; Huo, H.; Zhang, Q.; Yao, Z.; Wang, X.; Yang, X.; Liu, H.; He, K. High-resolution mapping of vehicle emissions in China in 2008. Atmos. Chem. Phys. 2014, 14, 9787-9805. [CrossRef]

63. Li, M.; Zhang, Q.; Streets, D.; He, K.; Cheng, Y.; Emmons, L.; Huo, H.; Kang, S.; Lu, Z.; Shao, M.; et al. Mapping Asian anthropogenic emissions of non-methane volatile organic compounds to multiple Chemical me-chanisms. Atmos. Chem. Phys. 2014, 14, 5617-5638. [CrossRef]

64. Zhang, Q.; Streets, D.; Carmichael, G.; He, K.; Huo, H.; Kannari, A.; Klimont, Z.; Park, I.; Reddy, S.; Fu, J.; et al. Asian emissions in 2006 for the NASA INTEX-B mission. Atmos. Chem. Phys. 2009, 9, 5131-5153. [CrossRef]

65. MEIC. Available online: http://www/.meicmodel.org/ (accessed on 20 October 2019).

66. Zhou, Y.; Xing, X.; Lang, J.; Chen, D.; Cheng, S.; Wei, L.; Wei, X.; Liu, C. A comprehensive biomass burning emission inventory with high spatial and temporal resolution in China. Atmos. Chem. Phys. Discuss. 2016, 1-43. [CrossRef]

67. NCEP. Available online: https://doi.org/10.5065/D6M043C6 (accessed on 1 September 2019).

68. Stockwell, W.; Middleton, P.; Chang, J.; Tang, X. The second generation regional acid deposition model Chemical mechanism for regional air quality modeling. J. Geophys. Res. Atmos. 1990, 95, 16343-16367. [CrossRef]

69. Schell, B.; Ackermann, I.; Hass, H.; Binkowski, F.; Ebel, A. Modeling the formation of secondary organic aerosol within a comprehensive air quality model system. J. Geophys. Res. Atmos. 2001, 106, 28275-28293. [CrossRef] 
70. Ackermann, I.; Hass, H.; Memmesheimer, M.; Ebel, A.; Binkowski, F.; Shankar, U. Modal aerosol dynamics model for Europe: Development and first applications. Atmos. Environ. 1998, 32, 2981-2999. [CrossRef]

71. Hong, S.; Noh, Y.; Dudhia, J. A new vertical diffusion package with an explicit treatment of entrainment processes. Mon. Weather Rev. 2006, 134, 2318-2341. [CrossRef]

72. Fels, S.; Schwarzkopf, M. An efficient, accurate algorithm for calculating CO2 $15 \mu \mathrm{m}$ band cooling rates. J. Geophys. Res. Atmos. 1981, 86, 1205-1232. [CrossRef]

73. Chou, M.; Suarez, M. A solar radiation parameterization for atmospheric studies. NASA Tech. Memo. 1999, 15,40 .

74. Lin, Y.; Farley, R.; Orville, H. Bulk Parameterization of the snow field in a cloud model. J. Clim. Appl. Meteorol. 1983, 22, 1065-1092. [CrossRef]

75. Ek, M.; Mitchell, K.; Lin, Y.; Rogers, B.; Grunmann, P.; Koren, V.; Gayno, G.; Tarpley, J. Implementation of NOAH land surface model advances in the National Centers for Environmental Prediction operational mesoscale Eta model. J. Geophys. Res. 2003, 108, 8851. [CrossRef]

76. Xu, Z.; Liu, M.; Song, Y.; Zhang, M.; Wang, S.; Xu, T.; Zhang, L.; Wang, T.; Yan, C.; Zhou, T.; et al. High efficiency of livestock ammonia emission controls on alleviating particulate nitrate during a severe winter haze episode in northern China. Atmos. Chem. Phys. 2019, 19, 5605-5613.

77. Liu, M.; Huang, X.; Song, Y.; Xu, T.; Wang, S.; Wu, Z.; Hu, M.; Zhang, L.; Zhang, Q.; Pan, Y.; et al. Rapid SO2 emission reductions significantly increase tropospheric ammonia concentrations over the North China Plain. Atmos. Chem. Phys. 2018, 18, 17933-17943. [CrossRef]

78. Liu, M.; Huang, X.; Song, Y.; Tang, J.; Cao, J.; Zhang, X.; Zhang, Q.; Wang, S.; Xu, T.; Kang, L.; et al. Complex Impacts of Ammonia Emission Control in China: Improved Haze Pollution, Reduced Nitrogen Deposition, but Worsened Acid Rain. Proc. Natl. Acad. Sci. USA 2018, 116, 7760-7765. [CrossRef]

79. Yao, H.; Song, Y.; Liu, M.; Archer-Nicholls, S.; Lowe, D.; McFiggans, G.; Xu, T.; Du, P.; Li, J.; Wu, Y.; et al. Direct radiative effect of carbonaceous aerosols from crop residue burning during the summer harvest season in East China. Atmos. Chem. Phys. 2017, 17, 5205-5520. [CrossRef]

80. Liu, L.; Huang, X.; Ding, A.; Fu, C. Dust-induced radiative feedbacks in north China: A dust storm episode modeling study using WRF-Chem. Atmos. Environ. 2016, 129, 43-54. [CrossRef]

81. Gao, M.; Carmichael, G.R.; Saide, P.E.; Lu, Z.; Yu, M.; Streets, D.G.; Wang, Z. Response of winter fine particulate matter concentrations to emission and meteorology changes in North China. Atmos. Chem. Phys. 2016, 16, 11837-11851. [CrossRef]

82. NCEI. Available online: https://gis.ncdc.noaa.gov/maps/ncei/cdo/hourly (accessed on 20 July 2019).

83. Kwok, R.H.; Fung, J.C.; Lau, A.K.; Fu, J.S. Numerical study on seasonal variations of gaseous pollutants and particulate matters in Hong Kong and Pearl River Delta Region. J. Geophys. Rse. Atmos. 2010, 115, D16308. [CrossRef]

84. Zhang, Y.; Liu, P.; Pun, B.; Seigneur, C. A comprehensive performance evaluation of MM5-CMAQ for the Summer 1999 Southern Oxidants Study episode Part I: Evaluation protocols, databases, and meteorological predictions. Atmos. Environ. 2006, 40, 4825-4838. [CrossRef]

85. Boylan, J.; Russel, A. PM and light extinction model performance metrics, goals, and criteria for three-dimensional air quality models. Atmos. Environ. 2006, 40, 4946-4959. [CrossRef]

86. Liao, J.; Wang, T.; Jiang, Z.; Zhuang, B.; Xie, M.; Yin, C.; Wang, X.; Zhu, J.; Fu, Y.; Zhang, Y. WRF/Chem modeling of the impacts of urban expansion on regional climate and air pollutants in Yangtze River Delta, China. Atmos. Environ. 2015, 106, 204-214. [CrossRef]

87. Zhang, Y.; Wen, X.Y.; Jang, C.J. Simulating Chemistry-aerosol-clould-radiation-climate feedbacks over the continental U.S. using the online-coupled Weather Research Forecasting Model with Chemistry (WRF/Chem). Atmos. Environ. 2010, 44, 3568-3582. [CrossRef]

88. Borne, K.; Chen, D.; Nunez, M. A method for finding sea breeze days under stable synoptic conditions and its application to the swedish west coast. Int. J. Climatol. 1998, 18, 901-904. [CrossRef]

89. Furberg, M.; Steyn, D.G.; Baldi, M. The climatology of sea breezes on Sardinia. Int. J. Climatol. 2002, 22, 917-932. [CrossRef]

90. Azorin-Molina, C.; Tijm, S.; Chen, D. Development of selection algorithms and databases for sea breeze studies. Theor. Appl. Climatol. 2011, 106, 531-546. [CrossRef] 
91. Miao, J.F.; Chen, D.; Wyser, K.; Borne, K.; Lindgren, J.; Strandevall, M.K.S.; Thorsson, S.; Achberger, C.; Almkvist, E. Evaluation of MM5 mesoscale model at local scale for air quality applications over the Swedish west coast: Influence of PBL and LSM parameterizations. Meteorol. Atmos. Phys. 2008, 99, 77-103. [CrossRef]

92. Arritt, R. Effects of the Large-Scale flow on Characteristic features of the sea breeze. J. Appl. Meteorol. 1992, 32, 116-125. [CrossRef] 